\title{
The Implications of Foreign Language Teaching Apprehension on EFL Prospective Teachers' Pedagogical Choices
}

\author{
By \\ Randa M. Safyeddin Kharboush, Ph.D.*
}

\section{Theoretical background}

While most of the apprehension research mainly focuses on the identification of apprehension, its causes and effects on the learning process, FLTA has remained an ignored research area that has not attracted much attention, even though the teacher is a substantial stakeholder in the overall success of every student in the class. Considering that the number of students in any average Egyptian classroom can range from double digits to much higher, being accountable for teaching English as a foreign language (EFL) successfully for such a range of unique individuals with varying expectations, aims, learning styles, needs, and beliefs can be a quite challenging task for any teacher. As stated by Horwitz, (1996), EFL teachers, as non-native of the foreign language (FL) they are teaching, are expected to stand before large live participative audiences as a specialist expert of their subject matter on a daily basis.

Research in the field of FLA, in general, has been focusing on FL learning apprehension experienced by students, putting the teacher out of focus. According to Horwitz (1996) it is sometimes forgotten that non-native EFL teachers are also EFL learners, even if they are very advanced users of the target language (TL), language learning process is infinite. Thus, it is feasible that non-native EFL teachers may experience a sense of inadequacy from time to time. According to Horwitz, Horwitz, \& Cope, 1986, most of them reported strong speaking anxiety and indicate their inadequate speaking ability as the strongest barrier in FL communication. They were afraid of being ridiculed and not accepted as an authority by their students.

\footnotetext{
* Lecturer of Curriculum\& EFL Instruction - Faculty of Education,
} Benha University. 
For non-native EFL teachers, there is the added burden of conducting the class in a language that is not their native language. Horwitz (1996) indicates that the widespread belief that those teachers are expected to be proficient in the TL and have a full operational command over it triggers a lot of stress and may cause FLTA. If FL education context emphasizes communicative competence, it is expected that teachers are effective communicators in the TL that is not native to them. Such high expectations can also generate feelings of inadequacy, which in turn can lead to teachers' FLTA.

Horwitz (1996) was the first researcher, using the Teacher Foreign Language Anxiety Scale (TFLAS), to propose that nonnative teachers and prospective teachers may experience feelings of FLA. Despite the fact that FLTA can have a number of undesirable effects on FL instruction, not enough research has been conducted on it (Horwitz, 1996; Canessa, 2004; Tseng, 2005). FLTA has the potential to negatively influence FL teachers' performance, use of the target language, pedagogical choices, and overall success, which intensify research in the area.

The challenges faced by non-native prospective teachers are most probably just as intimidating as those faced by teachers. Generally, teacher education programs integrate micro-teaching sessions and teaching practice ones into their syllabus. During junior and senior years, prospective teachers find themselves, for the first time, in the role of a "teacher" in front of a class. It can easily be assumed that this is quite a challenge for them since they are still developing their knowledge of the practice of teaching and have very little or no teaching experience in actual classrooms. Such teaching practice sessions are also observed and graded by an evaluator. This adds to the pressure of such experiences. Additionally, non-native prospective teachers have the challenge of conducting these microteaching sessions and teaching practice in the TL, which most of them are still trying to develop at this stage. The research conducted by Kunt (1997), Kunt (2005), and Kunt \& Tum (2010), has shown that non-native prospective teachers experience indications of FLA during micro-teaching sessions. Thus, it is likely that the situation of non-native FL prospective teachers is just as, or maybe even more, challenging than that of non-native FL teachers. When the potential effects of FLTA are considered, it is clear that more research is needed in this area (Borg, 2006). 
The current study attempted to bridge the gap and highlight the implications underlying ELTA and its effect on prospective teachers of English in the Egyptian context. This might help the prospective teachers as well as the curriculum designers to get a better understanding of such a phenomenon in order to find practical academic solutions, which might help to alleviate the level of ELTA among prospective teachers. This study aims to shed more light on ELTA through conducting empirical research on this phenomenon and examining how ELTA affects FL classroom instruction, through investigating its effect on the prospective teachers' choice of instructional activities.

\section{Research objectives}

The current research investigates ELTA among Egyptian prospective teachers of English. This includes its level and its effect on their choice of instructional activities they use when teaching. It also aims to find out the correlation between ELTA and classroom instruction, and how does ELTA influence teaching performance.

In the following sections the researcher will first, review the related literature, and the studies previously conducted on nonnative prospective teachers' FLTA; then present the research questions, methodology (design, participants, and instruments of this study), data analysis, then conclude with the findings and their interpretations, and finally, its implications for teacher training programs and suggestions for further research.

\section{Review of related literature}

\section{Foreign language apprehension (FLA)}

Despite the fact that the objective of the present research is to explore ELTA as experienced by the prospective teachers before and while teaching, it is important to consider the effect of this aspect of the study on the learners themselves. It has to be recognized that FLA is a problem that can equally affect the teachers, in just the same way it does their students. Since apprehension can have profound impacts on many aspects of teachers' performance and students' learning, it is important to identify those stressors which particularly provoke apprehension in teaching a FL. It is interesting that although extensive research has been conducted on learner FLA, little empirical research has been conducted on FLTA. Horwitz (1996) considers this point by explaining that the focus of researchers has traditionally been on learners' FLA and on establishing a 
relaxed, non-stressful, and non-confrontational FL classroom setting. There are, however, a variety of things the FL teachers can do to seek to alleviate their students' FLA.

Apprehension or anxiety, as used interchangeably, has been regarded as an important affective variable in language classrooms. FLA is a phenomenon experienced among FL learners who are not fully proficient during a specific situation, which requires the use of the target language (Horwitz \& Young, 1991, Gardner \& MacIntyre, 1993, Aydin, 2008). It is classified into three varieties: (1) communication apprehension, which is experienced when learners lack mature communication skills while they have mature thoughts and ideas, (2) test anxiety which refers to the fear of failing in tests, and (3) fear of negative evaluation which is an apprehension based on the incapability of making a proper social impression.

Research results show that FLA constitutes a considerable problem in the FL learning process among learners. Thus, many studies focused on identification of apprehension, its causes and effects on the learning process and the ways to allay it or cope with it, but FLTA has remained a research area that has not received enough attention. Tum (2012) emphasizes that issue when comparing the number of studies on FL learning apprehension to those on FLTA; the latter remains too limited to draw conclusions.

Based on Young's interview (1992), with four language specialists, Krashen, Hadley, Terrell, and Rardin, Hadley's recommendations for managing language anxiety contain avoiding putting students on the spot or concentrating on their errors, permitting open-ended responses in addition to discrete-point responses, fostering small group practice, putting emphasis on what students say instead of just on how they say it, and changing instructor attitudes toward mistakes. All these strategies may be applicable to the EFL prospective teachers.

Modeling and reinforcement in the makeup of FLA has its role from the point of view of teaching practice: with their authority in the classroom, the instructors are capable of either facilitating a positive attitude and promoting progress by encouraging the trainee to perform as best they can, or they can choose to "shut them down" by focusing on errors and pointing out the negative aspects in their output. As McCroskey (1977) points out, eliciting a response from a student with high FLA may only worsen the situation. He recommends that teachers should accommodate such individuals and come up with ways of getting through the class without a high 
requirement for communication. However, this is a highly problematic suggestion with regard to developing fluency in a FL. Petting EFL prospective teachers and keeping them from having to communicate will backfire sooner or later, when they begin to go out for work as EFL teachers that requires them to communicate using the TL. Gregersen and Horwitz (2002) claim that perfectionism in the EFL classroom is an unwelcome trait, linked to feelings of language anxiety and inadequacy; teachers as well as learners should be encouraged to explore and make mistakes.

To sum up, EFL instructors should strive to make the classroom environment as non-hostile to communication as possible for the interest of their apprehensive prospective teachers. Whenever they feel that the atmosphere in the class is safe, they can try out their skills without the feelings of embarrassment or judgment. It is critical that the teacher show the students that mistakes and errors are a part of the language learning process, not causes for guilt and shame.

\section{Foreign language teaching apprehension (FLTA)}

Just as apprehension prevents some people from acting successfully, many individuals consider FL learning and teaching stressful and apprehension stimulator. Based on studies conducted in the field, it can be argued that many teachers experience one type of apprehension or more while teaching. The first type of studies that investigated and analyzed teachers' apprehension, anxiety, and stress emerged during the 1960s. Henceforth, the teacher's stress has gained a major interest in research throughout the world. When it comes to the process of teaching, there may be confusion between the terms: apprehension, stress, and anxiety, but they can be considered as synonymous in language teaching. The experience of unpleasant, negative emotions, such as anger, anxiety, tension, frustration or depression are symptoms of stress gained as a result of some facets of their work as teachers. Kyriacou (2001) considered this as a negative emotional experience, triggered by the teacher's perception that FLTA constituted a threat to their self-esteem or well-being. Kyriacou's study (2001) indicated that most teachers appear to face a period of self-doubt, disenchantment and reconsideration, in which their concerns are either fixed with them continuing with their job as teachers or their decision to leave.

FLTA was first tackled by Horwitz (1996) in terms of nonnative teachers and prospective teachers' experiences. She pointed 
out that those teachers experience feelings of uneasiness and inadequacy using the $T L$, and the repeated and frequent feelings of inadequacy during their teaching experience can develop FLTA, which consequently has negative ramifications on their competence as FL teachers. She maintains that FLTA adversely affects teachers' self-confidence, their use of the target language and instructional choices. The crucial point asserted by Horwitz (1996) was that teachers experience the feeling of apprehension as they are still language learners. However, teaching and learning are different from each other contextually; FLA in the learning context may differ from FLTA in the teaching context. Merc (2011) emphasizes that the effects and implications of FLTA are issues that concern the greater community of all teachers worldwide. According to Horwitz (2001), the large number of language learners and language teachers who have personal experiences with tension and discomfort related to language learning, call for the attention of the language teaching profession.

One of the challenges the phenomenon of apprehension poses on the teacher is to have a level of awareness to be able to attribute the problem and the feeling of discomfort to the correct source. Gregersen (2003) advocates that often, EFL learners/teachers' unwillingness to communicate in English is linked in their mind to lack of motivation or poor attitude. The job of the teacher, whether teaching a FL or any other subject, is one which presupposes a certain level of communicative readiness and ability. Therefore, it is important to admit that some teachers may not always have a high willingness to communicate, despite their occupational choice. In fact, teachers with a high level of apprehension can foster a very negative classroom environment. Considering the teachers' status, influence and power that rest upon their shoulders, it is a real risk for the students ending up suffering from apprehension as well. Teachers should make all possible attempts and exert their efforts to better know themselves and their students and get a picture of what their inclination to communication is like.

Horwitz (1996), who is considered the patroness of FLA and FLTA field, argues that even though teachers of FL may be experts at their craft, the process of acquiring a language is one which does not have a decisive endpoint. What this entails is that instructors sometimes experience the same type of discomfort and feelings of inadequacy as the language learners do. As with their students, the teachers can show symptoms of this apprehension in their practice. 
One major implication maybe those teachers are more prone to refrain from the use of the $T L$ in the classroom. If the teachers are apprehensive and anxious about communicating in the TL, this will place great mental stress on them. Besides, the situational components, such as focused attention on the speaker, with an outspoken large audience, and other external components such as pressure from supervisors and observers, it can be understood why teaching a FL can place great stress and psychological challenges on the teacher.

Even though language teachers are supposed to be advanced speakers of the TL, sometimes they indicate a considerable amount of apprehension. Having studied the TL as a FL, non-native teachers might have difficulty expressing their ideas in the TL. Hence, they may experience apprehension and suffer from some amount of anxiety or stress now and then. According to Horwitz (1996), the problem stems from the fact that the more anxious an EFL teacher is, the less $s$ /he can encourage students to do their best in learning the TL which will definitely affect EFL instruction.

\section{Review of Related Previous Studies}

One of the first research projects conducted on FLTA appears to be Horwitz (1996)'s groundbreaking study. She puts forward that it is not unrealistic to assume that non-native FL teachers experience apprehension incidents in the classroom. In this study, she proposed a number of reasons as to why teachers are subject to FLTA: First, she assumed that most FL teachers, being high achievers in language learning, are more likely to experience feelings of FLTA. Second, FL teachers are susceptible for FLTA since they have invested a significant amount of time and effort in language learning. Third, Horwitz suggests that the unpredictable flow of communication in FL classrooms which emphasizes spontaneous target language use can be a reason for FLTA since the teacher is prone to making mistakes in vocabulary and language use. Fourth, she proposes that FL teachers with unrealistic expectations in regards to proficiency in the TL are more likely to experience anxiety over their own levels of competency; no matter how accomplished they are as FL speakers. Lastly, FL teachers' apprehension-inducing incidents during their own past experiences learning the TL can also lead to teachers develop feelings of FLTA.

Further support for the existence of FLTA was put forward by Gregerson and Horwitz (2002). In their study on pre-service FL 
teachers, they identified a source of FLTA such as perfectionist tendencies; setting high unachievable standards. The authors claimed that it is how pre-service teachers emotionally react to their limitations in the TL rather than to recognize them that can be apprehension provoking. Fear of peers' evaluation and consequently appearing foolish was also seen as a contributor to FLTA. The study ends up with a conclusion that when all of these factors are considered as a whole, it is plausible to assume that non-native FL teachers are susceptible for FLTA.

Two of the important empirical studies on FLTA were conducted by Horwitz (1992; 1993). In these studies, one of the most remarkable findings was that anxious FL teachers were less likely to use innovative, language intensive activities and teaching approaches, including Total Physical Response (TPR), TL discussions, grammar explanations in the TL, and role-play activities; which were new trends at that time, even if they had previously rated these teaching approaches as being conducive for FL instruction. Based on these findings, Horwitz identified a number of potential undesirable effects that FLTA might have; some were classroom instruction related, and others about teachers 'well-being and job satisfaction.

As the teacher and classroom activities are the FL learners' main source of TL input, avoiding the use of intensive language teaching approaches will restrict the students' access to spontaneous use of the TL. Finally, Horwitz hypothesized that students are likely to pick up on their teachers' uneasiness in using the TL, which may foster anxious feelings in students and hinder the development of their confidence in using the TL. One of her major assumptions was that higher FLTA levels carried the risk of reducing the students' access to the TL since the teacher generally is the main source of input in the FL classroom. Kunt (2005) supported the same assumption when he carried out a study with non-native EFL prospective teachers and found that the participants experienced considerable levels of FLTA, and he drew the attention to the potential negative effects it could have on classroom instruction and overall teachers' well-being.

Kunt and Tum (2010) conducted a mixed method study to explore the levels of FLTA experienced by non-native FL prospective teachers, and to explore how it affected their feelings while using the TL. The instruments used in this study were the Turkish version of Horwitz's (1986) FLCAS, and a set of open-ended questions. The 
researchers concluded that the responses of the participants demonstrated that non-native prospective teachers experienced various levels of FLA to a degree that had the potential to affect their teaching performance. In the same study, Kunt and Tum (2010) recommended that FL teacher educators have to recognize nonnative prospective teachers' FLTA rather than just focusing on evaluating them. Furthermore, they suggested that teacher educators need to listen to non-native prospective teachers' worries concerning the TL with an open mind and to be nonjudgmental and supportive of their struggles with the TL, FLTA, and teaching.

Tum (2010) in his study, carried out a study with 79 nonnative EFL teachers and 131 non-native EFL student teachers enrolled in teacher education programs to examine if the diverse participants experienced the feelings of FLTA and inspect the relationship between personal features and the levels of anxiety experienced. The student teacher participants were found to experience higher levels of FLTA than non-native EFL teachers. The results indicated that non-native prospective teachers participating in micro-teaching sessions experienced considerably higher levels of FLTA than those who did not involve a practical teaching aspect like micro-teaching. In response to open-ended items added to the FLTAS, these prospective teachers showed some perfectionist tendencies similar to those recorded by Gregerson and Horwitz (2002).

Paker (2011) conducted a study to investigate student teachers' anxiety related to the teaching practice. The purposes of this study were to examine the sources of apprehension of 101 Turkish student teachers, and to compare between male and female participants, using gender as a variable. The results Paker concluded in his study supported Horwitz's assumption (1996), revealing that student teachers' apprehension decreased after they finished their teaching practice. Tum (2012) studied apprehension and insufficiency feelings as encountered by non-native student teachers when using English during their practical teaching experience. This study found that 19 percent of the participating student teachers were found to be highly anxious when using English; their anxiety scores were higher than the mean which was calculated as 2.6. Moreover, 27 percent of the participants had their TFLAS scores higher than 3. In a more recent research, Rajab, Nor, Zakaria, Shaari, Abdul Rahman, and Mansor (2017) studied teacher trainee's apprehension towards teaching practice in schools. Their research 
findings indicated that the teacher trainees suffered from high anxiety for teaching skills and classroom management factors, moderate anxiety for language skills and low anxiety for other factors.

Sources of foreign language teaching apprehension (FLTA)

Many researchers and language educators were interested in discovering the sources of teachers' apprehension and anxieties and they considered FLTA a matter of high importance (Thompson, 1963; Kyriacou, \& Stephens, 1999; Merc, 2004, Paker, 2011, Barahmeh, 2016), and they agreed that it might have a negative impact on their teaching performance. Many researchers tackled the different sources of FLTA and found that apprehension provoking situations included:

- The feeling of insufficiency in grammar teaching, giving instructions for activities, and time management (Numrich, 1996).

- The use of target language, unexpected questions, a high level of learners' proficiency, a low level of motivation and interest among learners, classroom management, mentor observations, and teaching cultural content (Kim and Kim (2004).

- Low level of language proficiency, lack of self-confidence, poor content knowledge, insufficient class preparation, lack of teaching experience and fear of negative evaluation (Kim and Kim, 2004).

- Cultural background of the teachers was found to be a serious factor on the level of their FLTA (Canessa, 2004).

- Previous teaching experiences, crowded classrooms, mentor observations, unfamiliar teaching techniques, difficulties in time management, learners' levels, unfamiliarity with technology and fear of failure (Merc, 2004).

- Fear of making mistakes, lack of content knowledge, the use of native language, lack of target language proficiency, being compared to other teachers, limited language teaching levels, fear of failure in teaching a particular language area (Ipek, 2007)

- Teachers felt anxious when they taught low English proficient students (Kongchan and Singhasiri, 2008).

- Students and class profiles, classroom management, teaching procedures and mentor observations (Merc, 2011). 
- Teachers' language proficiency. More English teaching experience less FLTA (Machida, 2011).

- The use of target language, lack of self-confidence and lack of preparation (Yoon, 2012).

- Personality, teaching and supervision context (Sammephet \&Wanphet, 2013).

- Lack of teaching experience (Agustiana, 2014).

- Classroom management, time management, lesson planning, being observed, and fluency in the TL (Barahmeh, 2016).

\section{Correlation studies}

Some correlation studies explored the relationship between FLTA and different factors, and they concluded that:

- There was a negative correlation between the level of FLTA and effectiveness in English language teaching. Apprehensive teachers were proved to be less effective in their teaching performance (Williams, 1991).

- The relationship between FLTA and self-efficacy beliefs, the participants experienced a moderate level of FLTA (El-Okda \& Al-Humaidi, 2003).

- There was a negative correlation between teaching experience and the level of apprehension (Canessa, 2004).

- There was no significant relationship between the level of apprehension and educational background or spending some time in the target language speaking countries (Canessa, 2004).

- Gender and FLA were not significantly correlated with FLTA. The participants had low level of apprehension (Yuksel, 2008).

- The relationship between students' communication apprehension (CA) and their choice of instructional communicative activities; as participants had a comparatively high level of $\mathrm{CA}$, they preferred group discussion as a way of reducing their CA (Mustapha, Ismail, Singh, and Alias, 2010).

- There was a low correlation between self-efficacy and apprehension awareness (Gungor \& Yayl, 2012).

- Gender was not a significant variable that might affect FLTA (Aslrasouli \& Vahid (2014).

- Novice instructors had a lower level of FLTA when compared to experienced teachers (Aydin, 2016). 
In short, it is pointed out in this respect that teachers' inexperience, fear of failure and making mistakes and negative evaluation in addition to lack of self confidence are main sources of FLTA. Prospective teachers' self-perception of low level of TL proficiency is another source of FLTA. Additionally, other factors that provoke FLTA are students' high level of TL proficiency, as well as their low level of motivation and interest in classes. Students' unexpected questions and their usage of native language during classes also cause FLTA. Insufficient class preparation and difficulties in time management, crowded classroom, and technology increase FLTA among prospective teachers. It can be deduced from this review of research that teachers' personality is one of the main sources of FLTA. It also shows that FLTA is correlated with teaching experience and self-efficacy self beliefs, while no correlation exists in terms of gender.

\section{Consequences of FLTA}

While many studies focused on the sources of FLTA, only a few studies appeared on the effects of FLTA:

- Tum (2012) found that apprehension had adverse effects on pre-service teachers' use of TL and pedagogical competence.

- Goodwin, Roegman \& Reagan (2016) noted that beginner or novice teachers usually encounter several challenges; different types of apprehension, and anxieties during their first year that may contribute to feelings of frustration, insufficiency, stress or isolation.

- According to Farrell's study (2016), 24 percent of teachers dropped out of teaching within the first year, 33 percent left after three years and between 40 percent and 50 percent quitted within the first five years. Farrell's claim that "Teaching is the profession that eats its young" is a dramatic statement.

\section{Coping with FLTA}

Horwitz (1996) suggested a number of ways for reducing FLTA.

- To start with, FL teachers need to recognize it is acceptable that they may experience feelings of FLTA from time to time.

- Then, they need to set realistic expectations for their TL proficiency and performance and should acknowledge and appreciate their achievements in the TL. 
- Horwitz advises teachers to become familiar with relaxation techniques, such as imagining speaking well when faced with difficulties in the classroom, deep-breathing, and progressive relaxation exercises.

- Familiarizing with the language learning process and developing a plan to improve language proficiency are also suggested as methods for alleviating apprehension.

- On the institutional level, Horwitz stresses the importance of being supportive of colleagues and pre-service teachers to ensure they develop confidence.

Accordingly, it can be inferred from the review of previous studies that apprehension in general, and FLA in particular, adversely affects prospective teachers' use of TL and pedagogical competence. Despite all the studies done in the field of FLA, very few ones have focused on FLTA.

As a non-native EFL learner who experienced the feeling of FLA during her EFL learning process, the present researcher got interested in focusing on the affective states of EFL instruction, specifically ELA. After she started working as a teacher trainer and researcher, she noticed that prospective teachers are experiencing teaching anxiety in general and ELTA in particular, and it looked like an untouched research area in Egypt. Thus, the topic of the present study seemed significant to the researcher, as she proved in a previous study (2017) that the students at Education Faculty are suffering from ELA. To be brief, the researcher intended to study prospective teachers' ELTA and to investigate its effects on some of their pedagogical choices that might affect their teaching performance.

So, the present study was carried out under the guidance of several factors. Apprehension in a FL context was mainly researched in the learning context, so the current study attempted to investigate it in the teaching context, and it is obvious that learning and teaching are contextually different. The correlation between FLTA and the choice and use of the different EFL instructional approaches and activities were not fully investigated; therefore the present study was trying to fill in this gap.

\section{Limitations of the study}

The current study attempted to investigate the previously unexplored feelings of FLTA of Egyptian EFL prospective teachers, but it had some limitations that need to be kept in mind. 
- It only focused on Egyptian EFL prospective teachers, but inservice EFL teachers were not included in the present study.

- The current study is limited to only quantitative research methods and collected no qualitative data on ELTA.

- It remains unknown if the findings of the current study could be generalized to Egyptian prospective teachers of other foreign languages; French and German.

\section{Significance of the study}

To the best knowledge of the researcher, this study was one of the first kind of to be conducted in Egypt on ELTA, and it might have predominant significance in several respects;

- The results of this study might help the participants have an opportunity to be aware of FLTA and to observe their feelings during their teaching practice.

- The current study could also provide researchers, cooperating teachers, mentors, as well as faculty instructors with some insight into this phenomenon and good enough information to make those prospective teachers aware of those stressors and their consequences before they commence teaching.

- It might give the participants, as EFL students, an insight to have a better picture of themselves in their minds, so as to boost their self-esteem. Their confidence might be raised accordingly and they could overcome shyness, avoid going through tough times of feeling apprehensive, stressed-out, and reach the peak of their career.

- It hopefully could ensure the participants that they could have more effective teaching by overcoming their apprehension, by being passionate in and about teaching.

- It also explored the potential consequences of ELTA on FL classroom instruction and teaching performance.

\section{Research questions}

Based on the review of previous studies, the researcher aimed at filling some of the gaps in the field of FLTA by investigating ELTA among Egyptian prospective teachers of English, and to explore its potential effects on classroom instruction.

This study addressed the following questions:

1. Do Egyptian EFL prospective teachers experience ELTA? 
2. What level of ELTA do prospective teachers of English at Faculty of Education experience?

3. Is there any correlation between ELTA level and the participants' choice of instructional activities?

4. What is the effect of ELTA on EFL classroom instruction?

\section{Method}

\section{Design \& participants}

The study participants were ninety three prospective teachers; (juniors $=49$, seniors $=44$ ) at the Faculty of Education, Benha University. The reason for that choice was that they had some kind of classroom experience during their teaching practice, in which they conduct EFL lessons in real classrooms. They had to teach a predetermined number of EFL lessons throughout the duration of the school year, and those lessons had to be observed mainly by a supervisor from the Ministry of Education, or a staff member nominated formally by the Faculty of Education, and by a cooperating teacher as well.

\section{Instruments}

The study participants were given a battery of three separate questionnaires combined to form a whole single unit to complete. These three questionnaires had previously been used in previous studies conducted by Horwitz (1996), Canessa (2004), and Tum (2010), and they had been adapted and modified to suit the present study. Their validity and reliability had been established. The battery of questionnaires (See appendices) aimed to: (a) gather background information of the participants in the study, (b) elicit the participants' feelings of ELTA and to evaluate its levels, and (c) find out the participants' opinion and likelihood of using EFL instructional activities out of 20 pre-assigned ones.

The first part of the battery was for background information about the participants. The second component of consisted of 21 items with a five-point Likert-type scale, ranging from 'strongly agree', 'agree', 'neither agree nor disagree', 'disagree', to 'strongly disagree' for each item. Participants were asked to grade each item according to their personal opinions. Some modifications and adjustments were made to the questionnaires, and the changes had been presented to some specialist jury members, to change the FLTAS to ELTAS. ELTAS was used to elicit their responses reflecting the existence of ELTA and its level. The factor analysis of 
the ELTAS ranged from 0.808 to 0.447 and total item correlation values were found to be between 0.71 and 0.48 . Additionally, the reliability coefficient of the scale was 0.91 , and Spearman-Brown split half correlation was 0.85 . In the end, Cronbach's Alpha reliability coefficients of the factors were calculated with the results 0.87 to 0.81 .

The third component of the battery was a questionnaire that provides a list of 20 activities for EFL instruction (Tum, 2010). For this questionnaire, two five-point Liker-type scales were provided. One scale aimed at rating the participants' opinions of the provided EFL instructional activities. It consisted of 'very good', 'good', 'neither good nor bad', 'poor', and 'very poor' type of rating. The other scale included "very likely to use", "likely to use", "not sure", "unlikely to use", and "very unlikely to use" rating, to indicate how likely the participants would use each instructional activity in their own teaching. Its aim is to investigate whether ELTA affects Egyptian EFL prospective teachers' pedagogical choices; and thus, classroom instruction and teaching performance. A couple of new items were added in order to update the teaching approaches and techniques listed in the questionnaire. So, "Using authentic listening materials" and "Task-based activities" were added as new items to the questionnaire. Furthermore, the item "A notional syllabus" was changed to "A communicative syllabus" to avoid confusion on the part of the participants, and the jury members approved such change. Lastly, the format of this questionnaire was changed. In the initial version, each activity was marked as a separate question with two scales. The researcher combined them into one scale with two rating options, and the jury members commended this modification. Participants were requested to mark their responses to every item of the questionnaire on one scale with the two ratings; once for their opinions on the instructional activity and the other time about the likelihood of using it.

\section{Data collection \& analysis}

The questionnaires were distributed to the prospective teachers, in their classroom at the end of one of their lectures to be collected after being filled in; junior and senior data were kept separate throughout the process. Later, the data was checked for participants who had not completely filled in the questionnaire, and the incomplete ones were removed. Then the collected data were statistically treated and analyzed to get the results. 
The ELTAS has 21 items and it is scored on a 5-point scale, ranging from (5) strongly agree to (1) strongly disagree; some of these items are reverse-scored. ELTAS aims to measure the participants' ELTA and its levels, through eliciting their feelings about their English proficiency and self-confidence. To determine their apprehension level, their responses to all the items were added up; taking into consideration the reverse-scored items, then divide the total by 21 , which is the total number of items. With the maximum score of each item being 5 , the highest score a participant could obtain from the 21 items was a total of 105 . A score of 105 would indicate that the participant was highly anxious; in other words, experienced the highest possible levels of ELTA. The items 2, 4, 8, 10, $11,12,14,16,17,18$ and 20 were reverse-scored because they have negative connotations. Descriptive statistics was use to calculate each individual participant's score, then the average score of the participants within- group to compare within the group's members and across-groups; juniors and seniors, and later for all participants. The participants were grouped according to their ELTA scores. Three groups were established according to anxiety-level: highanxious, mid-anxious and low-anxious. They were as follows:

Sum of the Mean + SD ========= $\rightarrow$ High Anxious

Sum of the Mean $-\mathrm{SD}========\rightarrow$ Low Anxious

The remaining participants were placed into the mid-anxious group.

The final part of the questionnaire presented participants with a list of EFL instructional activities. Participants were asked to rate their opinion of them and to decide how likely they would use them in teaching their own classrooms. This section of the questionnaire contains 20 EFL instructional activities and two five-point Likerttype scales. On the first scale, participants were requested to mark their opinion, while they were asked to rate how likely they were to use the activity on the second scale. The first scale ranged from very good (A) to very poor (E) and the second scale ranged from very likely to use (5) to very unlikely to use (1). Each response on the scale was assigned a score; (A) very good = five points, (B) good = four points, (C) neither good nor bad $=$ three points, (D) poor $=$ two points, and (E) Very poor $=$ one points, and the same was done for the likelihood.

When analyzing the data, the EFL instructional activities were divided into two main categories: high demanding activities and low demanding activities, and the jury members agreed on this classification. The first category, the high-demanding activities, included language-intensive linguistically and communicatively 
demanding EFL instructional activities. On the other hand, the second category, the low-demand activities, contains those activities that were considered less linguistically and communicatively demanding activities. Table 1 presents the classification and grouping of English language instructional activities.

Table 1. EFL instructional activities classified according to the intensity of linguistic demand

\begin{tabular}{|l|l|}
\hline High-demanding activities & Low-demanding activities \\
\hline 1. Role-play activities & 1. Pattern drills \\
\hline 2. A communicative syllabus & 2. A grammatical syllabus \\
\hline 3. Total physical response & $\begin{array}{l}\text { 3. Grammatical explanations in } \\
\text { Arabic }\end{array}$ \\
\hline 4.Grammatical explanation in English & 4. Translation \\
\hline 5. Pair-work and small-group activities & 5. Written grammar exercises \\
\hline 6. Using authentic reading materials & 6. Pronunciation exercises \\
\hline 7. Using authentic listening materials & \\
\hline 8. Whole-class discussions in English & \\
\hline 9- Language learning games & \\
\hline $\begin{array}{l}\text { 10- Dialogue journals } \\
\text { learning strategies in English }\end{array}$ & \\
\hline $\begin{array}{l}\text { 12. Describing some of your experiences } \\
\text { in English }\end{array}$ & \\
\hline 13. Task-based activities & \\
\hline $\begin{array}{l}\text { 14. Explaining the target culture in } \\
\text { English }\end{array}$ & \\
\hline
\end{tabular}

\section{Research results}

The findings of the ELTAS analysis showed that the participants had high levels of affective anxieties, i.e. fear of negative evaluation, i.e. worrying about being corrected for every mistake by their observer or supervisor. Many of them believed that speaking skill was the most apprehension-provoking, while some others expressed their apprehension in all four skills. As for the other component of the battery, the results showed that EFL prospective teachers preferred group and pair work to individual activities as they were more relaxing and less apprehension-provoking. The following section will present the findings in details for research question. 


\section{Research Question 1}

Do Egyptian EFL prospective teachers experience ELTA?

As previously mentioned, the study, specifically, examined whether Egyptian EFL prospective teachers experience feelings of ELTA, thus the participants were ninety three Egyptian EFL prospective teachers; (juniors $=49$, seniors $=44$ ) at the Faculty of Education, Benha University. After administering the FLTA scale, the participants' scores in each item in the ELTAS was statistically treated to get the mean and the standard deviation, and Table 2 shows the results.

Table 2. Participants' ELTA ratings

\begin{tabular}{|l|l|l|l|l|}
\hline \multirow{2}{*}{ Item } & \multicolumn{2}{|l|}{ Junior particants } & \multicolumn{2}{l|}{ Senior participants } \\
\cline { 2 - 5 } & M & SD & M & SD \\
\hline 1 & 3.75 & 1.01 & 3.54 & 1.17 \\
\hline 2 & 2.91 & 1.20 & 2.52 & 1.19 \\
\hline 3 & 3.75 & 1.05 & 3.75 & 1.12 \\
\hline 4 & 2.63 & 1.39 & 2.86 & 1.33 \\
\hline 5 & 3.10 & 1.06 & 3.25 & 1.18 \\
\hline 6 & 3.00 & 1.15 & 3.63 & 1.20 \\
\hline 7 & 3.36 & 1.01 & 3.50 & 1.04 \\
\hline 8 & 3.02 & 1.36 & 2.97 & 1.37 \\
\hline 9 & 3.46 & 1.17 & 3.47 & 1.28 \\
\hline 10 & 2.36 & 1.30 & 2.25 & 1.27 \\
\hline 11 & 3.85 & 0.91 & 3.09 & 1.23 \\
\hline 12 & 2.42 & 1.02 & 2.77 & 1.17 \\
\hline 13 & 3.59 & 1.05 & 3.27 & 1.40 \\
\hline 14 & 2.89 & 1.14 & 3.04 & 1.23 \\
\hline 15 & 3.04 & 1.51 & 3.75 & 1.10 \\
\hline 16 & 2.61 & 1.18 & 2.45 & 1.08 \\
\hline 17 & 2.24 & 1.14 & 2.15 & 1.01 \\
\hline 18 & 2.95 & 1.39 & 2.47 & .848 \\
\hline 19 & 2.89 & 1.12 & 2.90 & 1.34 \\
\hline 20 & 2.28 & 0.84 & 2.20 & 1.11 \\
\hline 21 & 3.53 & 1.24 & 3.00 & 1.44 \\
\hline
\end{tabular}

The results in Tables 2, present the participants' rating of each item in the scale based on its mean score. The higher the mean score of the item is the more apprehension- provoking level it has and vice versa. Ranking the items according to the mean had some variation between junior participants and senior ones. For junior participants ranking the items was as follows: 11, 3, 1, 13, 21, 9, 7, 5, 
$15,8,6,18,2,19,14,4,16,12,10,20$, and 17. But for the senior participants, it goes: $3,15,6,1,7,9,13,5,11,14,21,8,19,4,12,2$, $18,16,10,20$, and 17.

In short, the results of the ELTAS suggest that the study participants experience feelings of ELTA. Furthermore, the findings indicate that the sources of ELTA can differ from one participant to the other and the reasons may vary as well. For example, worrying about making mistakes while teaching English occupied the top of the list for the junior participants, while being anxious about the students' testing their knowledge in English was at the top of the seniors rating. Both junior and senior participants agreed on the item that's was least apprehension-provoking which was speaking English with native speakers whenever possible, and that was interesting, maybe because they were thinking of rarity of its occurrence.

The total score of each participant was calculated, and then the mean and the standard deviation of all the participants, both juniors and seniors were calculated.

Table 3. Participants' ELTA means and standard deviations according to year of study

\begin{tabular}{|l|l|l|l|}
\hline Year of study & Number of participants & Mean & Standard deviation \\
\hline Juniors & 49 & $\mathbf{3 . 1 9}$ & $\mathbf{0 . 4 4}$ \\
\hline Seniors & 44 & $\mathbf{3 . 0 0}$ & $\mathbf{0 . 5 5}$ \\
\hline
\end{tabular}

Comparing the results of junior EFL prospective teacher participants with those of senior indicated that the means are almost the same and there is a slight difference between their standard deviations. Hence, all EFL prospective teacher participants experience ELTA, and there is no statistically significant difference between juniors and seniors.

\section{Research Question 2}

\section{What level of ELTA do Egyptian prospective teachers of} English at faculty of education experience?

The findings of the current study indicate that Egyptian EFL prospective teachers experience feelings of ELTA with varying levels. Some participants were found to experience it at considerably high levels while others were experiencing it on lower levels. Participants were sub grouped into three categories according to their ELTA scores; high-anxious, mid-anxious, and mid-anxious. 
Juniors' statistical equations were as follows:

Sum of the Mean + SD ========= $\rightarrow$ High Anxious

$3.19(\mathrm{M})+0.44(\mathrm{SD})=3.63$

Sum of the Mean $-\mathrm{SD}========-\rightarrow$ Low Anxious

$3.19(\mathrm{M})-0.44(\mathrm{SD})=2.75$

The same procedure was followed with senior prospective teacher participants to categorize them into low-anxious, mid-anxious, and high-anxious.

Seniors' statistical equations were as follows:

Sum of the Mean $+\mathrm{SD}========+\rightarrow$ High Anxious

$3.00(\mathrm{M})+0.55(\mathrm{SD})=3.55$

Sum of the Mean $-\mathrm{SD}========-\rightarrow$ Low Anxious

$3.00(\mathrm{M})-0.55(\mathrm{SD})=2.45$

Table 4 shows the mean, standard deviation, in addition to participants' percentage under each level of ELTA, for both juniors and seniors separately.

Table 4. Egyptian EFL prospective teacher participants' ELTA category levels

\begin{tabular}{|c|c|c|c|c|c|c|c|c|c|}
\hline \multirow[t]{2}{*}{$\begin{array}{l}\text { Year of } \\
\text { study }\end{array}$} & \multirow[t]{2}{*}{$\begin{array}{l}\text { Number of } \\
\text { participants }\end{array}$} & \multirow[t]{2}{*}{ Mean } & \multirow[t]{2}{*}{$\begin{array}{l}\text { Standard } \\
\text { deviation }\end{array}$} & \multicolumn{2}{|c|}{$\begin{array}{l}\text { Low- } \\
\text { anxious }\end{array}$} & \multicolumn{2}{|c|}{$\begin{array}{l}\text { Mid- } \\
\text { anxious }\end{array}$} & \multicolumn{2}{|c|}{$\begin{array}{l}\text { High- } \\
\text { anxious }\end{array}$} \\
\hline & & & & $\mathbf{N}$ & $\%$ & $\mathbf{N}$ & $\%$ & $\mathbf{N}$ & $\%$ \\
\hline Juniors & 49 & 3.19 & 0.44 & 13 & $26.5 \%$ & 31 & $63.3 \%$ & 5 & $10.2 \%$ \\
\hline Seniors & 44 & 3.00 & 0.55 & 8 & $18.2 \%$ & 28 & $63.6 \%$ & 8 & $18.2 \%$ \\
\hline
\end{tabular}

Table 4 manifests categorized ELTA levels among prospective teacher participants. As shown in the table, the majority of the participants, both juniors and seniors, tend to be in the mid-anxious category. It turned out that the majority of the participants are experiencing average level of ELTA; 31junior participants and 28 seniors, with almost the same percentage; nearly at equal levels. However, there were also a considerable percentage of the participants who were placed under the high level of ELTA; 10.2\% of juniors and $18.2 \%$ of seniors. It is apparent that the level of ELTA is higher among senior participants, and this is may be due to the fact that they went through more teaching experience during teaching practice.

Then the descriptive statistics for all participants were calculated. The mean score was 3.02 and the standard deviation was 0.49. The upper quartile and the lower quartile were estimated in order to categorize all the participants as high-anxious, mid anxious, and low-anxious. 
3.38 $=======-\rightarrow$ was the cut-off point for High Anxious

$2.67=======-\rightarrow$ was the cut-off point for Low Anxious

Sum of the Mean $+\mathrm{SD}========\rightarrow$ High Anxious

$3.02(\mathrm{M})+0.49(\mathrm{SD})=3.51$

Sum of the Mean $-\mathrm{SD}========-\rightarrow$ Low Anxious

3.02 $(\mathrm{M})-0.49(\mathrm{SD})=\mathbf{2 . 5 3}$

Table 5 shows the results of all participants mean scores, standard deviation, and percentages of each ELTA category.

Table 5. ELTA ratings for Egyptian EFL prospective teacher participants by level of apprehension

\begin{tabular}{|l|l|l|l|l|l|l|l|l|l|}
\hline $\begin{array}{l}\text { Prospective } \\
\text { teachers }\end{array}$ & N & M & SD & \multicolumn{2}{|l|}{ Low-anxious } & \multicolumn{2}{|l|}{ Mid-anxious } & \multicolumn{2}{|l|}{ High-anxious } \\
\cline { 5 - 10 } & & & & N & $\%$ & N & $\%$ & N & $\%$ \\
\hline All & $\mathbf{9 3}$ & $\mathbf{3 . 0 2}$ & $\mathbf{0 . 4 9}$ & $\mathbf{1 8}$ & $\mathbf{1 9 . 4 \%}$ & $\mathbf{5 7}$ & $\mathbf{6 1 . 3 \%}$ & $\mathbf{1 8}$ & $\mathbf{1 9 . 4 \%}$ \\
\hline
\end{tabular}

Accordingly, the results indicates that the vast majority; almost-two thirds, of the Egyptian EFL prospective teacher participants $(61.3 \%)$ in the current study experience average/medium level of ELTA. It is also found that a substantial percentage $(19.4 \%)$ of the participants are high anxious and experience high level of ELTA. It is obvious that the number of participants with low level of ELTA (18) is equal to those experiencing high level of ELTA (18). This finding is in line with previous research, as chronologically ordered; Gregerson \& Horwitz (2002), Merc (2004, 2011) Kunt (2005), Kunt \& Tum (2010), Paker (2011), Tomohisa (2011), Yoon (2012), Agustiana (2014), and Rajab \& Abdul Rahman (2017).

\section{Research Question 3}

Is there any correlation between ELTA level and the participants' choice of instructional activities?

The third component of the research instrument aimed to elicit the participants' opinions and likelihood of using various EFL instructional activities. To answer the third question of the study, the correlation between the participants' level of ELTA and their opinion of such instructional activities was investigated. These activities were classified into two categories according to how linguistically demanding each activity is; high-demand and lowdemand. 
The mean score and standard deviation for each of the twenty

EFL instructional activities, as shown in Table 6, was calculated for EFL prospective teacher participants' opinion on each activity.

Table 6. Participants' opinions on the EFL instructional activities

\begin{tabular}{|c|c|c|c|c|}
\hline \multirow[t]{2}{*}{ EFL Instructional activities } & \multicolumn{2}{|c|}{ Juniors } & \multicolumn{2}{|c|}{ Seniors } \\
\hline & $\mathbf{M}$ & SD & $\mathbf{M}$ & SD \\
\hline 1. Role-play Activities & 4.57 & 0.57 & 4.50 & 0.66 \\
\hline 2. Pattern Drills & 4.10 & 0.84 & 3.86 & 1.01 \\
\hline 3. A Communicative Syllabus & 4.32 & 0.77 & 4.02 & 0.82 \\
\hline 4. A Grammatical Syllabus & 3.75 & 1.12 & 3.97 & 0.66 \\
\hline 5. Total Physical Response & 4.08 & 0.99 & 3.61 & 0.96 \\
\hline 6. Grammatical Explanations in English & 4.18 & 1.01 & 4.31 & 0.77 \\
\hline 7. Grammatical Explanations in Arabic & 3.12 & 1.21 & 3.40 & 1.12 \\
\hline 8. Pair-work and Small-group Activities & 4.57 & 0.84 & 4.47 & 0.87 \\
\hline 9. Using Authentic Reading Materials & 4.34 & 0.72 & 4.27 & 0.81 \\
\hline 10. Using Authentic Listening Materials & 4.26 & 0.86 & 4.11 & 0.89 \\
\hline 11. Translation & 4.24 & 0.99 & 4.18 & 0.81 \\
\hline 12. Whole-class Discussions in English & 4.28 & 0.91 & 4.09 & 1.03 \\
\hline 13. Language Learning Games & 3.87 & 1.12 & 4.11 & $\mathbf{1 . 0 8}$ \\
\hline 14. Dialogue Journals & 3.55 & 0.95 & 3.70 & $\mathbf{1 . 0 2}$ \\
\hline $\begin{array}{l}\text { 15. Discussions of Effective Language Learning } \\
\text { Strategies in English }\end{array}$ & 4.12 & $\mathbf{0 . 8 3}$ & 4.06 & 0.75 \\
\hline 16. Written Grammar Exercises & 4.40 & 0.70 & 4.22 & 0.85 \\
\hline $\begin{array}{l}\text { 17. Describing some of your Experiences in } \\
\text { English }\end{array}$ & 3.95 & 0.95 & 3.84 & 0.91 \\
\hline 18. Pronunciation Exercises & 4.10 & 1.06 & 4.22 & 0.98 \\
\hline 19. Task-based Activities & 4.10 & 0.98 & 4.02 & 0.95 \\
\hline 20. Explaining the Target Culture in English & 3.83 & $\mathbf{1 . 2 3}$ & 3.84 & 0.86 \\
\hline
\end{tabular}

Comparing the results shown above in table 6, it is clear that the mean score of all the items for both junior and senior EFL prospective teachers was almost exactly equal. The mean score for junior EFL participants was calculated as 4.09. Interestingly, the mean score for senior participants was 4.04. In other words, on average both junior and senior EFL prospective teacher participants rated the FL instructional activities as good. 
Table 7. EFL instructional activities categorized according to their linguistic demand (high-demanding/low-demanding)

\begin{tabular}{|c|c|c|c|c|c|}
\hline EFL Instructional activities & High/low & Min. & Max. & M & SD \\
\hline 1. *RP & H & 3.00 & 5.00 & 4.53 & 0.61 \\
\hline 2. *PD & $\mathbf{L}$ & 1.00 & 5.00 & 3.98 & 0.92 \\
\hline 3. *CS & H & 3.00 & 5.00 & 4.18 & 0.80 \\
\hline 4. *GS & $\mathbf{L}$ & 1.00 & 5.00 & 3.86 & 0.93 \\
\hline 5. *TPR & H & 1.00 & 5.00 & 3.86 & 1.00 \\
\hline 6. *GEE & H & 1.00 & 5.00 & 4.24 & 0.90 \\
\hline 7. *GEA & $\mathbf{L}$ & 1.00 & 5.00 & 3.25 & 1.17 \\
\hline 8. *PW & H & 1.00 & 5.00 & 4.52 & 0.85 \\
\hline 9. *ARM & $\mathbf{H}$ & 1.00 & 5.00 & 4.31 & 0.76 \\
\hline 10. *ALM & H & 2.00 & 5.00 & 4.19 & 0.87 \\
\hline 11. *T & $\mathbf{L}$ & 1.00 & 5.00 & 4.21 & 0.90 \\
\hline 12. *WCDE & H & 1.00 & 5.00 & 4.19 & 0.96 \\
\hline 13. *LLG & $\mathbf{H}$ & 1.00 & 5.00 & 3.98 & 1.10 \\
\hline 14. *DJ & H & 1.00 & 5.00 & 3.62 & 0.98 \\
\hline 15. *DESE & H & 2.00 & 5.00 & 4.09 & 0.79 \\
\hline 16. *WGE & $\mathbf{L}$ & 2.00 & 5.00 & 4.32 & 0.78 \\
\hline 17.*DEE & H & 1.00 & 5.00 & 3.90 & 0.93 \\
\hline 18. *PE & $\mathbf{L}$ & 2.00 & 5.00 & 4.16 & 1.02 \\
\hline 19. *TBA & $\mathbf{H}$ & 1.00 & 5.00 & 4.06 & 0.96 \\
\hline 20. *ETCE & $\mathbf{H}$ & 1.00 & 5.00 & 3.83 & 1.06 \\
\hline
\end{tabular}

$* \mathbf{R P}=$ Role-play Activities, $* \mathrm{PD}=$ Pattern Drills, ${ }^{*} \mathrm{CS}=\mathrm{A}$ Communicative Syllabus,

*GS = A Grammatical Syllabus, *TPR = Total Physical Response,

*GEA=Grammatical Explanations in English, ${ }^{*}$ GEA=Grammatical Explanations in Arabic, $* \mathbf{P W}=$ Pair-work and Small-group Activities, *ARM = Using Authentic Reading Materials, *ALM = Using Authentic Listening Materials, *T = Translation,

$*$ WCDE $=$ Whole-class discussions in English, ${ }^{*} \mathbf{L L G}=$ Language learning Games,

*DJ= Dialogue Journals, *DESE $=$ Discussions of effective language learning strategies in English, *WGE $=$ Written grammar exercises, ${ }^{* D E E}=$ Describing some of your Experiences in English, ${ }^{*} \mathbf{P E}=$ Pronunciation Exercises, $*$ TBA $=$ Task-based Activities, *ETCE = Explaining target culture in English

Primarily the current study revealed that the vast majority of the Egyptian EFL prospective teacher participants opted to rate most of the EFL instructional activities as being good or very good. This might indicate that participants' FLTA does not affect their opinions of EFL instructional activities. In fact, certain activities which were categorized as highly-demanding were rated as very good 
or good by nearly all participants. Horwitz (1996) in her study assumed that EFL prospective teachers might rate the activity as being favorable for the target language instruction, but still they would not use it if it is highly-demanding.

Table 8. EFL instructional activities ranked based on participants' opinions

\begin{tabular}{|c|c|c|c|c|c|}
\hline $\begin{array}{ll}\text { EFL } & \text { Instructional } \\
\text { activities } & \\
\end{array}$ & $\begin{array}{l}\text { High/low } \\
\text { demand }\end{array}$ & Min. & Max. & M & SD \\
\hline RP & $\mathbf{H}$ & 3.00 & 5.00 & 4.53 & 0.61 \\
\hline PW & H & 1.00 & 5.00 & 4.52 & 0.85 \\
\hline WGE & $\mathbf{L}$ & 2.00 & 5.00 & 4.32 & 0.78 \\
\hline ARM & $\mathbf{H}$ & 1.00 & 5.00 & 4.31 & 0.76 \\
\hline GEE & $\mathbf{H}$ & 1.00 & 5.00 & 4.24 & 0.90 \\
\hline $\mathbf{T}$ & $\mathbf{L}$ & 1.00 & 5.00 & 4.21 & 0.90 \\
\hline WCDE & $\mathbf{H}$ & 1.00 & 5.00 & 4.19 & 0.96 \\
\hline ALM & H & 2.00 & 5.00 & 4.19 & 0.87 \\
\hline CS & $\mathbf{H}$ & 3.00 & 5.00 & 4.18 & 0.80 \\
\hline PE & $\mathbf{L}$ & 2.00 & 5.00 & 4.16 & 1.02 \\
\hline DEES & $\mathbf{H}$ & 2.00 & 5.00 & 4.09 & 0.79 \\
\hline TBA & $\mathbf{H}$ & 1.00 & 5.00 & 4.06 & 0.96 \\
\hline LLG & $\mathbf{H}$ & 1.00 & 5.00 & 3.98 & 1.10 \\
\hline PD & $\mathbf{L}$ & 1.00 & 5.00 & 3.98 & 0.92 \\
\hline DEE & $\mathbf{H}$ & 1.00 & 5.00 & 3.90 & 0.93 \\
\hline GS & $\mathbf{L}$ & 1.00 & 5.00 & 3.86 & 0.93 \\
\hline TPR & $\mathbf{H}$ & 1.00 & 5.00 & 3.86 & 1.00 \\
\hline ETCE & H & 1.00 & 5.00 & 3.83 & 1.06 \\
\hline DJ & $\mathbf{H}$ & 1.00 & 5.00 & 3.62 & 0.98 \\
\hline GEA & $\mathbf{L}$ & 1.00 & $\begin{array}{l}5.00 \\
\end{array}$ & 3.25 & 1.17 \\
\hline
\end{tabular}

Looking at table 8, it is observable that role-play and pairwork and small-group activities came at the top of the list for most of the participants, even though they are the most highly-demanding linguistically and communicatively challenging.

Table 9. EFL instructional activities ranked according to participants' opinions (frequencies \& percentages)

\begin{tabular}{|c|c|c|c|c|c|c|c|c|c|c|}
\hline \multirow{2}{*}{$\begin{array}{l}\text { EFL } \\
\text { Instructional } \\
\text { Activities }\end{array}$} & \multicolumn{2}{|c|}{ A (5) } & \multicolumn{2}{|c|}{ B (4) } & \multicolumn{2}{|c|}{ C (3) } & \multicolumn{2}{|c|}{ D (2) } & \multicolumn{2}{|c|}{ E (1) } \\
\hline & $\mathbf{F}$ & $\%$ & $\mathbf{F}$ & $\%$ & $\mathbf{F}$ & $\%$ & $\mathbf{F}$ & $\%$ & $\mathbf{F}$ & $\%$ \\
\hline RP & 56 & $60.2 \%$ & 31 & $33.3 \%$ & 6 & $6.5 \%$ & $\mathbf{0}$ & $0 \%$ & $\mathbf{0}$ & 0\% \\
\hline PR & 65 & $69.9 \%$ & 17 & $18.3 \%$ & 7 & $7.5 \%$ & 3 & $3.2 \%$ & 1 & $1.1 \%$ \\
\hline WGE & 45 & $48.4 \%$ & 36 & $38.7 \%$ & 9 & $9.7 \%$ & 3 & $3.2 \%$ & $\mathbf{0}$ & 0\% \\
\hline ARM & 42 & $45.2 \%$ & 41 & $44.1 \%$ & 8 & $8.6 \%$ & 1 & $1.1 \%$ & 1 & $1.1 \%$ \\
\hline GEE & 44 & $47.3 \%$ & 34 & $36.6 \%$ & 11 & $11.8 \%$ & 2 & $2.2 \%$ & 2 & $2.2 \%$ \\
\hline$T$ & 43 & $46.2 \%$ & 33 & $35.5 \%$ & 12 & $12.9 \%$ & 4 & $4.3 \%$ & 1 & $1.1 \%$ \\
\hline WCDE & 45 & $48.4 \%$ & 28 & $30.1 \%$ & 15 & $16.1 \%$ & 3 & $3.2 \%$ & 2 & $2.2 \%$ \\
\hline ALM & 40 & $43 \%$ & 37 & $39.8 \%$ & 10 & $10.8 \%$ & 6 & $6.5 \%$ & $\mathbf{0}$ & $0 \%$ \\
\hline
\end{tabular}




\begin{tabular}{|l|l|l|l|l|l|l|l|l|l|l|}
\hline \hline CS & 40 & $43 \%$ & 30 & $32.3 \%$ & 23 & $24.7 \%$ & 0 & $\mathbf{0} \%$ & 0 & $0 \%$ \\
\hline PE & 47 & $50.5 \%$ & 24 & $25.8 \%$ & 12 & $12.9 \%$ & 10 & $10.8 \%$ & 0 & $0 \%$ \\
\hline DESE & 31 & $33.3 \%$ & 43 & $46.2 \%$ & 16 & $17.2 \%$ & 3 & $3.2 \%$ & 0 & $0 \%$ \\
\hline TBA & 35 & $37.6 \%$ & 37 & $39.8 \%$ & 16 & $17.2 \%$ & 2 & $2.2 \%$ & 3 & $3.2 \%$ \\
\hline LLG & 40 & $43 \%$ & 26 & $28 \%$ & 15 & $16.1 \%$ & 10 & $10.8 \%$ & 2 & $2.2 \%$ \\
\hline PD & 29 & $31.2 \%$ & 42 & $45.2 \%$ & 16 & $17.2 \%$ & 4 & $4.3 \%$ & 2 & $2.2 \%$ \\
\hline DEE & 29 & $31.2 \%$ & 32 & $34.4 \%$ & 27 & $29 \%$ & 4 & $4.3 \%$ & 1 & $1.1 \%$ \\
\hline GS & 23 & $24.6 \%$ & 45 & $48.4 \%$ & 15 & $16.1 \%$ & 9 & $9.7 \%$ & 1 & $1.1 \%$ \\
\hline TPR & 28 & $30.1 \%$ & 35 & $37.6 \%$ & 21 & $22.6 \%$ & 7 & $7.5 \%$ & 2 & $2.2 \%$ \\
\hline ETCE & 29 & $31.2 \%$ & 34 & $36.6 \%$ & 19 & $20.4 \%$ & 8 & $8.6 \%$ & 3 & $3.2 \%$ \\
\hline DJ & 20 & $21.5 \%$ & 30 & $32.3 \%$ & 33 & $35.5 \%$ & 8 & $8.6 \%$ & 2 & $2.2 \%$ \\
\hline GEA & 17 & $18.3 \%$ & 21 & $22.6 \%$ & 31 & $33.3 \%$ & 17 & $18.3 \%$ & 7 & $7.5 \%$ \\
\hline
\end{tabular}

Table 9 displays the results in frequency and percentage for each instructional activity. For instance, role-play activities were categorized as highly-demanding, but they came at the top of the list and were rated as either very good or good by $93.5 \%$ of the EFL prospective teacher participants. The remaining $6.5 \%$ rated the activity as neither good nor bad. A communicative syllabus which was also considered to be a highly-demanding activity was rated as either very good or good by $\mathbf{7 5 . 3 \%}$ of the teacher participants and neither good nor bad by the remaining $24.7 \%$. Similar results were also found for some other highly-demanding activities, for example, the pair-work and small-group activities were rated as very good, good, or neither good nor bad by $98.9 \%$ of the prospective teacher participants. Meanwhile, some of the low-demanding activities, such as the written grammar exercises $(87.1 \%)$, translation $(81.7 \%)$ and pronunciation exercises $(\mathbf{7 6 . 3 \%})$ were mostly rated as very good and good, and a few of the participants rated them as neither good or bad. Thus, it seems that FLTA has no effect on non-native EFL prospective teachers' opinions of FL instructional activities.

\section{Research question 4}

What is the effect of ELTA on EFL classroom instruction?

This part of the study aimed to examine how ELTA affects EFL classroom instruction. Horwitz (1996) postulate a number of negative effects FLTA may have on FL classroom instruction, and some of those effects may be related to the choice of instructional activities used the EFL classroom. To test the effect of ELTA on the participants' likelihood of using these activities in their classrooms, the mean scores of the participants' responses on the likelihood of using the assigned EFL instructional activities were calculated for 
each of them as shown in Table 10. The standard deviation for each activity was also estimated, for both junior and senior participants. When comparing the responses of the two groups of participants, it is clear that the means of their scores are close to each others in most activities.

Table 10. The participants' responses on the likelihood of using EFL instructional activities

\begin{tabular}{|l|l|l|l|l|l|}
\hline \multirow{2}{*}{ EFL Activities } & \multicolumn{2}{|l|}{ Junior participants } & \multirow{2}{*}{ EFL Activities } & \multicolumn{2}{l|}{ Senior participants } \\
\cline { 2 - 3 } & M & SD & & M & SD \\
\hline PW & 4.46 & $\mathbf{0 . 9 5}$ & PW & 4.50 & 0.90 \\
\hline GEE & 4.28 & 0.86 & GEE & 4.34 & 0.74 \\
\hline RP & 4.28 & 1.13 & RP & 4.31 & 0.95 \\
\hline WGE & 4.16 & 0.96 & WGE & 4.13 & 1.06 \\
\hline WCDE & 4.12 & 1.01 & T & 4.04 & 0.91 \\
\hline ARM & 4.08 & 0.83 & LLG & 4.02 & 1.06 \\
\hline DESE & 4.08 & 0.78 & TBA & 4.00 & 0.83 \\
\hline PE & 4.04 & 1.04 & WCDE & 3.93 & 0.99 \\
\hline T & 4.04 & 1.05 & PE & 3.93 & 1.26 \\
\hline TBA & 4.02 & 0.98 & ARM & 3.90 & 1. \\
\hline CS & 4.00 & 1.08 & GS & 3.88 & 0.89 \\
\hline PD & 3.97 & 0.96 & DESE & 3.86 & 0.97 \\
\hline ALM & 3.91 & 1.05 & DEE & 3.81 & 0.94 \\
\hline DEE & 3.79 & 1.17 & ALM & 3.81 & 1.10 \\
\hline TPR & 3.77 & 1.17 & ETCE & 3.79 & 0.90 \\
\hline GS & 3.75 & 1.16 & CS & 3.75 & 0.99 \\
\hline ETCE & 3.65 & 1.29 & PD & 3.70 & 1.09 \\
\hline LLG & 3.55 & 1.13 & DJ & 3.56 & 1.14 \\
\hline DJ & 3.38 & 1.11 & TPR & 3.40 & 1.01 \\
\hline GEA & 3.22 & 1.26 & GEA & 3.29 & 1.26 \\
\hline
\end{tabular}

The overall mean score, as in Tables 10, was calculated for both junior and senior EFL prospective teachers. The mean score of the EFL prospective teacher participants of juniors was noted to be $(M=3.93)$ while the mean score for senior turned to be almost the same; $(M=3.90)$. In other words, all the EFL prospective teacher participants were likely to use all of the activities mentioned in the questionnaire. But it is obvious that the probability or likelihood of using those activities with the different levels of linguistic intensity; the highly-demanding versus the low-demanding varies between juniors and seniors. They agreed on their choice of the top four activities; pair-work and small-group activities $(\mathrm{H})$, grammatical explanation in English $(\mathrm{H})$, role-play $(\mathrm{H})$, and written grammar exercises (L), three of which are highly-demanding and only one is a 
low-demanding activity. Interestingly, junior participants put translation ( $L$ ) and pronunciation exercises (L) at the top ten among the activities while seniors rank translation at the top five and pronunciation exercises at the top ten. All participants chose to use seven out of the top ten activities which are highly-demanding activities, even though a considerable number of them had already been diagnosed with high levels of FLTA.

Table 11. EFL instructional activities ranked according to participants' likelihood of using them (frequencies \& percentages)

\begin{tabular}{|c|c|c|c|c|c|c|c|c|c|c|c|c|c|}
\hline \multirow[t]{2}{*}{$\begin{array}{l}\text { EFL } \\
\text { activities }\end{array}$} & \multirow[t]{2}{*}{$\begin{array}{l}\text { High/ } \\
\text { low }\end{array}$} & \multirow[t]{2}{*}{$\mathbf{M}$} & \multirow[t]{2}{*}{ SD } & \multicolumn{2}{|c|}{$\begin{array}{l}\text { Very likely } \\
\text { (5) }\end{array}$} & \multicolumn{2}{|c|}{$\begin{array}{l}\text { Likely } \\
\text { (4) }\end{array}$} & \multicolumn{2}{|c|}{$\begin{array}{l}\text { Not sure } \\
\text { (3) }\end{array}$} & \multicolumn{2}{|c|}{$\begin{array}{l}\text { Unlikely } \\
\text { (2) }\end{array}$} & \multicolumn{2}{|c|}{$\begin{array}{l}\text { Very } \\
\text { unlikely } \\
\text { (1) }\end{array}$} \\
\hline & & & & $\mathbf{F}$ & $\%$ & $\mathbf{F}$ & $\%$ & $\mathbf{F}$ & $\%$ & $\mathbf{F}$ & $\%$ & $\mathbf{F}$ & $\%$ \\
\hline PW & $\mathbf{H}$ & 4.48 & 0.92 & 63 & $67.7 \%$ & 20 & $21.5 \%$ & 4 & $4.3 \%$ & 4 & $4.3 \%$ & 2 & $2.2 \%$ \\
\hline GEE & $\mathbf{H}$ & 4.31 & 0.80 & 44 & $47.3 \%$ & 38 & $40.9 \%$ & 8 & $8.6 \%$ & 2 & $2.2 \%$ & 1 & $1.1 \%$ \\
\hline RP & $\mathbf{H}$ & 4.30 & 1.05 & 52 & $55.9 \%$ & 29 & $31.2 \%$ & 5 & $5.4 \%$ & 2 & $2.2 \%$ & 5 & $5.4 \%$ \\
\hline WGE & $\mathbf{L}$ & 4.15 & 1.01 & 42 & $45.2 \%$ & 33 & $35.5 \%$ & 11 & $11.8 \%$ & 4 & $4.3 \%$ & 3 & $3.2 \%$ \\
\hline $\mathbf{T}$ & $\mathbf{L}$ & 4.04 & 0.98 & 36 & $38.7 \%$ & 34 & $36.6 \%$ & 16 & $17.2 \%$ & 5 & $5.4 \%$ & 2 & $2.2 \%$ \\
\hline WCDE & $\mathbf{H}$ & 4.03 & 1.00 & 35 & $37.6 \%$ & 36 & $38.7 \%$ & 15 & $16.1 \%$ & 4 & $4.3 \%$ & 3 & $3.2 \%$ \\
\hline TBA & $\mathbf{H}$ & 4.01 & 0.91 & 32 & $34.4 \%$ & 36 & $38.7 \%$ & 20 & $21.5 \%$ & 4 & $4.3 \%$ & 1 & $1.1 \%$ \\
\hline ARM & $\mathbf{H}$ & 4.00 & 1.01 & 33 & $35.5 \%$ & 39 & $41.9 \%$ & 11 & $11.8 \%$ & 8 & $8.6 \%$ & 2 & $2.2 \%$ \\
\hline PE & $\mathbf{L}$ & 3.99 & 1.14 & 41 & $44.1 \%$ & 26 & $28 \%$ & 13 & $14 \%$ & 10 & $10.8 \%$ & 3 & $3.2 \%$ \\
\hline DESE & $\mathbf{H}$ & 3.98 & 0.88 & 27 & $29 \%$ & 43 & $46.2 \%$ & 19 & $20.4 \%$ & 2 & $2.2 \%$ & 2 & $2.2 \%$ \\
\hline CS & $\mathbf{H}$ & 3.88 & 1.04 & 31 & $33.3 \%$ & 31 & $33.3 \%$ & 23 & $24.7 \%$ & 5 & $5.4 \%$ & 3 & $3.2 \%$ \\
\hline ALM & $\mathbf{H}$ & 3.87 & 1.07 & 30 & $32.3 \%$ & 36 & $38.7 \%$ & 15 & $16.1 \%$ & 9 & $9.7 \%$ & 3 & $3.2 \%$ \\
\hline PD & $\mathbf{L}$ & 3.85 & 1.03 & 29 & $31.2 \%$ & 32 & $34.4 \%$ & 24 & $25.8 \%$ & 5 & $5.4 \%$ & 3 & $3.2 \%$ \\
\hline GS & $\mathbf{L}$ & 3.81 & 1.04 & 27 & $29 \%$ & 35 & $37.6 \%$ & 21 & $22.6 \%$ & 7 & $7.5 \%$ & 3 & $3.2 \%$ \\
\hline DEE & $\mathbf{H}$ & 3.81 & 1.06 & 28 & $30.1 \%$ & 33 & $35.5 \%$ & 21 & $22.6 \%$ & 8 & $8.6 \%$ & 3 & $3.2 \%$ \\
\hline LLG & $\mathbf{H}$ & 3.77 & 1.12 & 31 & $33.3 \%$ & 27 & $29 \%$ & 20 & $21.5 \%$ & 13 & $14 \%$ & 2 & $2.2 \%$ \\
\hline ETCE & $\mathbf{H}$ & 3.72 & 1.12 & 27 & $29 \%$ & 30 & $32.3 \%$ & 24 & $25.8 \%$ & 7 & $7.5 \%$ & 5 & $5.4 \%$ \\
\hline TPR & $\mathbf{H}$ & 3.60 & 1.11 & 24 & $25.8 \%$ & 27 & $29 \%$ & 26 & $28 \%$ & 13 & $14 \%$ & 3 & $3.2 \%$ \\
\hline DJ & $\mathbf{H}$ & 3.47 & 1.12 & 19 & $20.4 \%$ & 28 & $30.1 \%$ & 30 & $32.3 \%$ & 10 & $10.8 \%$ & 6 & $6.5 \%$ \\
\hline GEA & $\mathbf{L}$ & 3.25 & 1.25 & 20 & $21.5 \%$ & 19 & $20.4 \%$ & 28 & $30.1 \%$ & 17 & $18.3 \%$ & $\mathbf{0}$ & $0 \%$ \\
\hline
\end{tabular}

Looking at table 11, it can be figured out that seven out the top ten chosen EFL instructional activities are linguistically-intensive and communicatively highly-demanding activities. Meanwhile the three low-demanding activities chosen occupied high rank in the likelihood of using them in the classroom; for example, the likelihood of using written grammar exercises have $80.7 \%$ between very likely and likely $(\mathrm{N}=75$ out of 93), as for the translation, $75.3 \%$ of the participants are very likely and likely to use it in their classrooms, and 67 participants out of the 93 are going to use pronunciation exercises as instructional activities in their teaching. Grammatical explanations in Arabic occupied the bottom of the whole list of the assigned EFL instructional activities. Apparently, the results are mixed; as the findings of the study indicate that FLTA does not have of effect on the likelihood of EFL prospective teachers using certain 
activities in their own FL classrooms, meanwhile it is affecting the likelihood of using some others.

The present study hypothesized the same assumption that Horwitz (1992 \& 1993) adopted in her two studies, which indicated that highly anxious non-native FL teachers and prospective teachers would refrain from using high demanding activities, even if they had evaluated those activities as being beneficial for the target language instruction. The participants' ratings of their opinions about the activity as well as for their likelihood of using it in FL classrooms were statistically treated. Participants' means, standard deviation and percentages for the high demanding activities and the low demand activities were calculated, using the score each item received on the continuum.

\section{Discussion and conclusions}

The first significant finding of the study is that Egyptian EFL prospective teachers, juniors and seniors, experience feelings of ELTA with varied levels. On the one hand, the majority of the participants were found to experience average levels of ELTA. However, on the other hand, there were also a considerable number of participants who were found to experience high levels of ELTA and others with low ELTA level. However, it is logical to assume that junior participants would experience more intensive feelings of ELTA; as they have no or little experience of real classroom during teaching practice, than senior ones; who already went through the experience of teaching practice. Thus, it is plausible that all prospective teacher participants, who generally have little or no practical classroom teaching experience relatively higher levels of FLTA.

A significant reason for FLTA is that prospective teachers may tend to set unrealistic goals for their proficiency and performance in the TL, and setting such unachievable standards, generally results in not being able to live up to them, which in turn leads to FLTA. In the current study, a considerable number of the participants stated in item 14 of ELTAS that they were not satisfied with the level of English proficiency they have achieved. A notable issue that the participants frequently raised is that the evaluative nature of teaching practice results in feeling nervous and anxious during the whole observation with many negative consequences on their performance and teaching abilities. Thus, this study provides support for Horwitz (1996), Canessa (2004) and Kunt \&Tum (2010) 
claims for the relationship between setting unrealistic goals and FLTA.

In short, and for these reasons, it is not surprising that Egyptian EFL prospective teachers may experience considerably high levels of FLTA. In the current study, it was found that highanxious EFL prospective teachers tended to overreact to their limitations in English. For example, through item 16 on the ELTAS, it was recorded that those participants get nervous to the point that they forget the things they know when speaking English. This finding is in line with Gregerson and Horwitz's (2002) claim that anxious learners tend to overreact to errors and limitations in the TL, which can be anxiety provoking.

Another reason for higher ELTA levels of Egyptian prospective teacher participants may be because they are expected to be experts of the TL. There is little tolerance for teachers making mistakes or not knowing about issues related to their field of expertise, and having to live up to such high expectations may be a provocative factor for ELTA. Canessa (2004) found that non-native Taiwanese, Korean, American, and Argentine FL teachers experience feelings of FLTA. To put in a nutshell, the current study added the Egyptian EFL prospective teachers to the literature in the field. It provided evidence that Egyptian EFL prospective teachers also experienced feelings of ELTA. The consistency in the findings of the current research strongly suggests that the necessary measures have to be taken to combat the feelings of FLTA of prospective teachers to make sure that that does not affect FL classroom instruction and to protect the overall well-being of prospective teachers and future teachers in Egypt.

The current study also attempted to examine the effects of ELTA on EFL classroom instruction and Egyptian EFL prospective teachers' pedagogical choices. Considering that the teacher and classroom activities are main sources of TL input for FL learners, ELTA negative effects could drastically limit the amount of language-input of learners. It is also claimed that it is possible that learners would pick up on their teachers' apprehension in the classroom, and this could engender feelings of anxiety in the learners too. The results of the current study partially agrees with the previous ones, as some of the high anxious participants refrain from using the high-demanding instructional activities, even though they already rated them, as very good and good, as beneficial for their teaching. Despite the fact that some EFL prospective teachers 
experienced higher levels of FLTA, they tended not only to highly rate their likelihood of using high- demanding activities, but they also tended to negatively rate the low-demanding activities, such as grammatical explanation in Arabic. At some other points, the current study found that FLTA levels of the participants did not affect their opinions or likelihood of using the assigned EFL instructional activities. In fact, the majority of the participants positively rated all of the activities regardless of their FLTA levels, and the results of the current research are conforming Canessa's study (2004).

This finding is interesting since the present study had hypothesized that highly anxious participants would avoid using the highly demanding activities in their classrooms. A possible reason for this result may be due to the content of the methodology courses the participants were studying, that advocate the use of languageintensive communicative teaching approaches and activities, while presenting the use of $\mathrm{LI}$ in the classroom is something to be avoided. Thus, their beliefs might have been influenced by what they are studying and it affected their responses accordingly.

\section{Implications of the study and suggestions for further research}

Not only are EFL prospective teachers generally still in the process of developing their command of TL they hope to teach one day, but they also have very little or no teaching experience, which can be assumed to intensify any apprehension they may experience during class. Furthermore, micro teachings, and teaching practice are usually observed and evaluated by teacher educators or teacher trainers and EFL prospective teachers experience considerable levels of anxiety because of such experiences. The current research suggests reducing the evaluative aspect of these experiences that could also potentially add to the feelings of FLTA experienced by EFL prospective teachers. These findings carry some noteworthy implications for teacher education programs; teacher educators and trainers who need to recognize the fact that EFL prospective teachers are susceptible candidates of FLTA. Moreover, they should try to alleviate any feelings of FLTA their trainees are experiencing before they initiate their teaching careers. They need to be familiar with techniques and guidelines to cope with ELTA so that they can provide support for EFL prospective teachers who may be experiencing it. Prospective teachers need to be aware that they are 
not alone in the feelings they are experiencing. To sum up, the findings of the current study carry a number of important practical implications for teacher education and teacher training programs that will help Egyptian EFL prospective teachers cope with their feelings of FLTA.

The results of this study bring with them a number of suggestions for further research in this field of study.

- Conducting similar studies with teachers teaching at different levels of education and in different contexts.

- The replication of the study with a larger sample, so that the results could be generalized to other populations.

- Empirical studies targeting different groups of FL teachers would be an interesting contribution to the current literature on FLTA.

- Future studies need to investigate the effects of FLTA with other FL, as it is plausible that the findings could be different for prospective teachers of other foreign languages.

- Examine FLTA through collecting qualitative data for further comprehension of the phenomenon, using interviews, recorded classroom observations, etc.

- To conclude, the present research provides strong evidence of the existence of FLTA as a debilitating affective field. It threw some suggestions, such as using coping strategies, to assist teacher educators to alleviate feelings of FLTA among EFL prospective teachers. As the number of EFL teachers continues to increase and when the potential negative effects of FLTA is considered, it is clear that further studies on FLTA are tremendously needed. 
References

Agustiana, V. (2014). Pre-service teachers' anxiety during teaching practicum. Journal of English Education, 2 (2), 174-182.

Aslrasouli, M., \& Vahid, M. (2014). An investigation of teaching anxiety among novice and experienced Iranian EFL teachers across gender. Procedia- Social and Behavioral Sciences, 98, 304- 313.

Aydin, S. (2008). An investigation on the language anxiety and fear of negative evaluation among Turkish EFL learners. Asian EFL Journal, 30, 421- 444.

Aydin, S. (2016). A qualitative research on foreign language teaching Anxiety. The Qualitative Report, 21 (4), 628- 642.

Barahmeh, M. (2016). A study of sources of EFL student teachers' anxiety during their practicum experience. European Journal of Research and Reflection in Educational Sciences, 4 (1), 1625.

Canessa, L. (2004). A study of non-native foreign language teachers and their feelings of foreign language teaching anxiety. Unpublished Master thesis, The University of Texas, Austin.

Farrell, T. (2016). From trainee to teacher: reflective practice for novice teachers. TESL Canada Journal, 33 (2), 85-86.

Goodwin, A., Roegman, R., \& Reagan, E. (2016). Is experience the best teacher? Extensive clinical practice and mentor teachers' perspectives on effective teaching. Urban Education, 51 (10), 1198-1225.

Gregersen, T., \& Horwitz, E. K. (2002). Language learning and perfectionism: Anxious and non-anxious language learners' reactions to their own oral performance. The Modern Language Journal, 86, 562-570.

Gregersen, T. (2003). To err is human: a reminder to teachers of language-anxious students. Foreign Language Annals, 36 (1), 25- 32.

Gungor, F., \& Yayli, D. (2012). Self-efficacy and anxiety perceptions of pre-service EFL teachers. In A. Akbarov \& V. Cook (Eds.), Approaches and Methods in Second and Foreign Language Teaching. 277-236.

Horwitz, E. K., Horwitz M., \& Cope. J. (1986). Foreign language classroom anxiety. The Modern Language Journal, 70, 125132. 
Horwitz, E. K. \& Young, D. J. (Eds.). (1991). Language Anxiety: From theory and practice to classroom implications. Englewood Cliffs, NJ: Prentice-Hall.

Horwitz, E. K. (1996). Even teacher get the blues: Recognizing and alleviating non-native teachers' feelings of foreign language anxiety. Foreign Language Annals, 29, 365-372.

Horwitz, E. K. (2001). Language anxiety and achievement. Annual Review of Applied Linguistics, 21, 112-126.

Horwitz, E. K. (2013). Becoming a language teacher: A practical guide to second language learning and teaching. Boston: Pearson Education, Inc.

Ipek, H. (2007). Foreign language teaching anxiety. Eskisehir:T.C. Anadolu Universitesi Yayinlari.

Kim, S.Y. \& Kim, J. H. (2004). When the learner becomes a teacher: foreign language teaching anxiety as an occupational hazard. English Teaching, 59 (1), 165.

Kongchan, C. \& Singhasiri, W., (2008). Teachers' anxiety about using L2 in EFL classroom. Proceedings of the $16^{\text {th }}$ Annual Korea TESOL International Conference: Responding to a Changing World. Seoul, Korea. pp. 145- 149.

Kunt, N. (1997). Anxiety and beliefs about language learning: A study of Turkish-speaking university students learning English in North Cyprus. Unpublished doctoral dissertation, The University of Texas, Austin.

Kunt, N. (2005). "Do prospective teachers experience foreign language anxiety?" First International Conference on English Language Teaching: Searching for Quality in ELT. LINCOM studies in second language teaching. 474-486. LINCOM publications: Germany.

Kunt, N. \& Tum, D. O. (2010). Non-native student teachers' feelings of foreign language anxiety. Procedia- Social and Behavioral Sciences, 2, 4672-4676.

Kyriacou, C. (2001). Teacher stress: directions for future research. Educational Review, 53 (1), $27-35$.

Machida, T. (2011). Teaching English for the first time: anxiety among Japanese elementary-school teachers. Unpublished Ph.D. dissertation. University of Illinois, Urbana-Champaign, Illinois.

MacIntyre, P. D. \& Gardner, R. (1994). The subtle effects of language anxiety on cognitive processing in the second language. Language Learning, 44, 283-305. 
McCroskey, J. (1977). Oral communication apprehension: a summary of recent theory and research. Human Communication Research, 4 (1), $78-96$.

Merc, A. (2004). Reflections of pre-service EFL teachers throughout their teaching practicum. What has been good? What has gone wrong? What has changed? Unpublished Master thesis. Anadolu University, Eskisehir.

Merc, A. (2011). Sources of foreign language student teacher anxiety: A qualitative inquiry. Turkish Online Journal of Qualitative Inquiry, 2 (4), 80- 94.

Mustapha, W., Ismail, N. , Singh, D., \& Alias, S. (2010). ESL students communication apprehension and their choice of communicative activities. AJTLHE, 2 (1), 22- 29.

Numrich, C. (1996). On becoming a language teacher: insights from diary studies. TESOL Quarterly, 30 (1), 131- 153.

Paker, T. (2011). Student teacher anxiety related to the teaching practicum. Journal of Educational Research, 42, 207- 224.

Rajab, A., Nor, F., Zakaria, W., Shaari, R., Abdul Rahman, H., \& Mansor, I. (2017). Teacher trainee's apprehension towards teaching practice in schools. Journal of Engineering and Applied Sciences, 12, 3472- 3476.

Sammephet, B. \& Wanphet, P. (2013). Pre-service teachers' anxiety an anxiety management during the first encounter in EFL classroom. Journal of Education and Practice.4, (2), 78- 87.

Thompson, M. (1963). Identifying anxieties experienced by student teachers. Journal of Teacher Education, 14 (4), 435- 439.

Tseng, C. (2005). Taiwanese English teachers' language anxiety: A comparison study between elementary school and high school teachers. Unpublished Master thesis, The University of Texas, Austin.

Tum, D. (2010). A study of non-native teacher's and student teachers feelings of foreign language teaching anxiety. Unpublished Master thesis, The University of Texas, Austin.

Tum, D. (2012). Feelings of language anxiety amongst non-native student teachers. Procedia, Social and Behavioral Sciences, 47, 2055- 2059

Williams, K. (1991). Anxiety and formal second/foreign language learning. RELC Journal, 22 (2), 19- 28.

Yoon, T. (2012. Teaching English through English: Exploring anxiety in non-native pre-service ESL teacher. Theory and Practice in Language Studies, 2 (6), 1099- 1107. 
مجلة كلية التربية بالإسماعيلية ـ العدد الثانى والأربعون - سبتمبر 1 1 ـ ب

Young, D. J. (1992). Language anxiety from the foreign language specialist's perspective: Interviews with Krashen, Omaggio Hadley, Terrell, and Rardin. Foreign Language Annals, 19, 439- 445.

Yuksel, I. (2008). Pre-service teachers' teaching anxiety: Its reasons and coping strategies. Proceedings of the IASK International Conference: Teaching and learning. pp. 335-344. 


\begin{abstract}
The current study aimed to investigate foreign language teaching apprehension (hereafter FLTA) among Egyptian prospective teachers of English and its effect on their pedagogical choices; i.e., how FLTA affects their choice of the instructional activities they prefer to use in teaching. The participants of the study were ninety three EFL prospective teachers (forty nine juniors and forty four seniors) at Benha Faculty of Education. The participants had to complete a battery that included ELTA scale and instructional activities questionnaires. Data were collected and statistically processed. The results indicated that the study participants experienced before, during and after their teaching practice which considerably affected their teaching performance. The study concluded that there were various sources of ELTA; among which were teachers' personality, perceptions of low level language proficiency, fear of negative evaluation, and teaching inexperience. The feeling of ELTA they experienced had its effect on their choice of instructional activities they had to use during teaching, which might affect FL classroom instruction in general. The study recommended that EFL teacher preparation programs and those for in-service teachers should include topics to raise awareness of FLTA and strategies to help them allay it or cope with it. The study proposed that there was a need to carry out future research studies for ways to eliminate or cope with FLTA of prospective teachers prior to the start of their teaching career Keywords: teaching English as a foreign language (EFL), prospective teachers of English, foreign language teaching apprehension (FLTA), pedagogical choices, instructional activities.
\end{abstract}


هافت الدراسة الحالية إلى بحث القلق اللغوي المصاحب لتدريس اللغة الأنجليزية لاى الطلاب المعلمين وأثره على خياراتهم التدريسية ؛ وتحديدا علي اختيارهم للأنثطة التعليمية

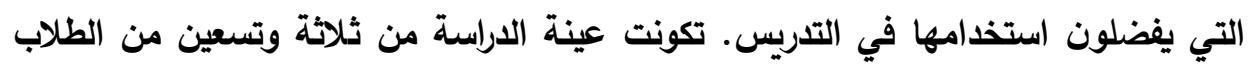

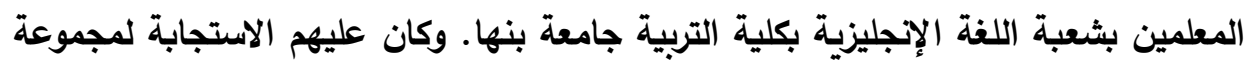

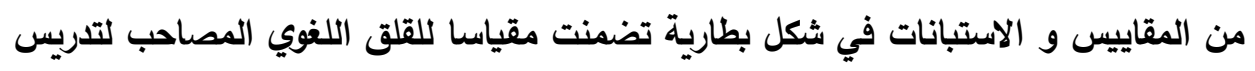

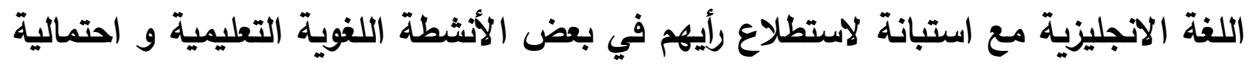

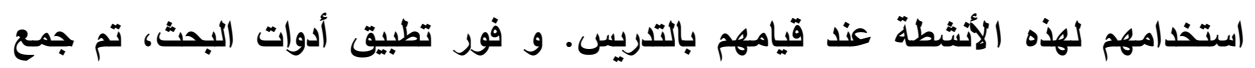

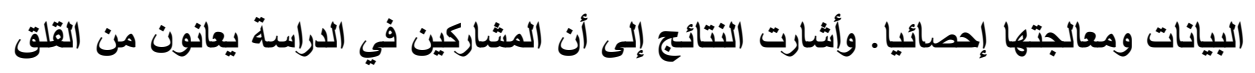

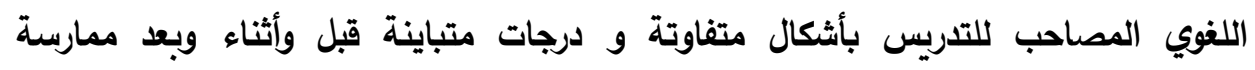

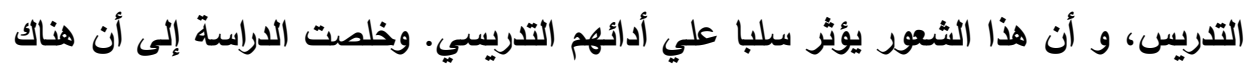
مصادر مختلفة للقلق اللغوي المصاحب للتدريس من بينها شخصية المعلمين، و تصوراتهم

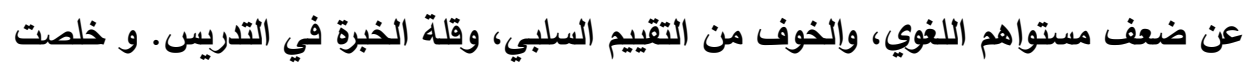

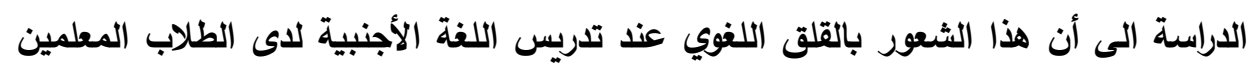

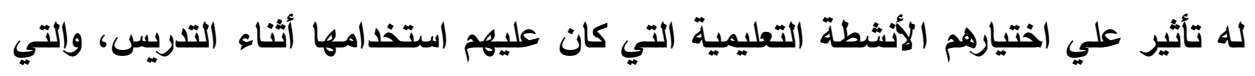

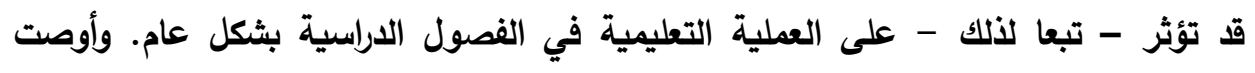

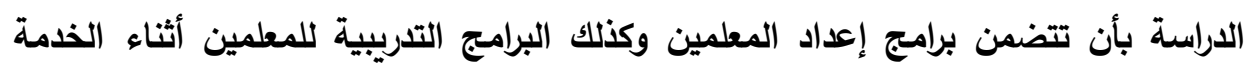

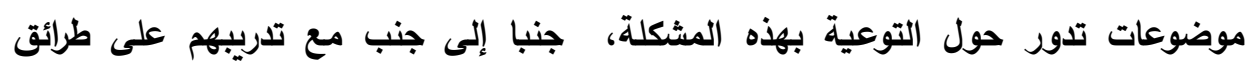

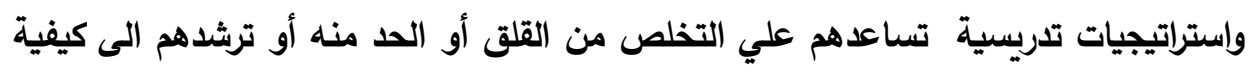

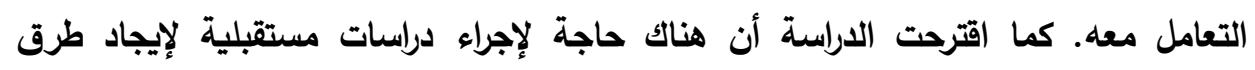

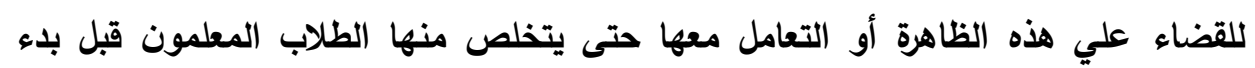
مسيرتهم التدريسية.

الكلمات الدالية: تدريس اللفة الانجليزية كلفة أجنبية - الطلاب المعلمون بشعبة اللغة

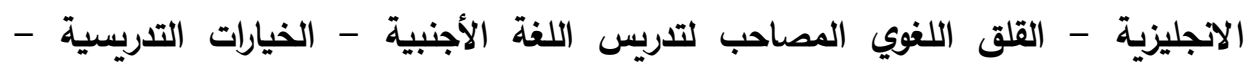
الأنشطة التعليمية. 